Kamil KRASUSKI ${ }^{1}$, Artur GOŚ ${ }^{1}$, Adam CIEĆKO ${ }^{2}$

${ }^{1}$ Military University of Aviation (Lotnicza Akademia Wojskowa)

${ }^{2}$ University of Warmia and Mazury (Uniwersytet Warmińsko-Mazurski)

\title{
THE RESEARCH INTO THE INTEGRITY PARAMETER IN AIR TRANSPORT USING GLONASS DATA
}

\section{Badanie parametru wiarygodności w transporcie lotniczym na podstawie danych GLONASS}

\begin{abstract}
The article presents the results of the integrity parameter of the GLONASS satellite positioning system in civil aviation. As a source material for the research the authors used observation and navigation data of the GLONASS system from the onboard GNSS receiver mounted on the Cessna 172. In the research, the authors used a model to determine the aircraft position based on the single-frequency SPP code method for GLONASS L1-C/A observations. The numerical calculations were conducted in the RTKLIB software, in the RTKPOST library. The obtained results are interesting from the point of using an application of the GLONASS system in aviation and the possible implementation of the single-frequency GLONASS code observations in the SPP model in order to determine the aircraft position. On the basis of the obtained results it was found that the GLONASS integrity performance data can be used in a procedure of non-precision approach to landing NPA GNSS.
\end{abstract}

Keywords: GPS, GLONASS, integrity, SPP code method, air transport

Streszczenie: W pracy przedstawiono wyniki badań parametru wiarygodności pozycjonowania satelitarnego GLONASS w lotnictwie cywilnym. Jako materiał do badań postużyly dane obserwacyjne i nawigacyjne GLONASS z pokładowego odbiornika GNSS zamontowanego na samolocie Cessna 172. Wykorzystano model wyznaczenia pozycji SP oparty na jednoczęstotliwościowej metodzie kodowej SPP do obserwacji GLONASS L1-C/A. Obliczenia numeryczne wykonano $w$ oprogramowaniu RTKLIB $w$ bibliotece RTKPOST. Uzyskane wyniki badań sq interesujace z punktu zastosowania systemu GLONASS w lotnictwie oraz możliwości implementacji jednoczęstotliwościowych obserwacji kodowych GLONASS w modelu SPP wyznaczenia pozycji statku powietrznego. Na podstawie uzyskanych wyników stwierdzono, że osiagi wiarygodności GLONASS moga zostać wykorzystane w procedurze nieprecyzyjnego podejścia do ladowania NPA GNSS.

Słowa kluczowe: GPS, GLONASS, wiarygodność, metoda kodowa SPP, transport lotniczy 


\section{Introduction}

The use of the GNSS satellite technique allows specifying four basic parameters of satellite positioning, i.e. accuracy, continuity, availability and integrity [1]. The parameter of accuracy is defined as a difference between determined coordinates of the aircraft and a precise reference position. The parameter of availability is defined as the working time of a service of a given GNSS navigation system in aviation. Besides, the parameter of continuity determines the number of failures of a given GNSS navigation system in aviation. The parameter of integrity determines the measure of integrity for the obtained findings of GNSS satellite navigation. Among the above-mentioned parameters of the quality of GNSS observations, integrity appears to be the most crucial one. Currently the performance of the navigation system GLONASS in aviation refers only to single-frequency receivers with an access to the civilian signal L1-C/A [4]. Therefore, the performance of accuracy, continuity, integrity and availability parameters are defined only for single frequency GLONASS receivers for the needs of air navigation.

This paper analyses and evaluates the use of single-frequency GLONASS receivers to determine the integrity parameter in aviation for approach to landing operations. The paper is scientific in its nature and its results may be implemented directly into practical use in aviation. The computations exploited real observation and navigation GLONASS data from an on-board receiver mounted in the Cessna 172. The paper is an important contribution to the development of the global GLONASS system in the airline industry, and is addressed to a wide range of recipients.

\section{Research method}

The parameter of integrity determines the measure of integrity for the obtained findings of GNSS satellite positioning in aviation. In aviation, integrity is examined by means of HPL safety levels for navigation in the horizontal plane and VPL for navigation in the vertical plane [3]. The integrity parameter is determined based on the following mathematical formulas, as below:

a) an approximate formula without taking into account a correlation between mean errors of the determined BLh ellipsoidal aircraft coordinates [7]:

$$
\left\{\begin{array}{c}
H P L=K_{H} \cdot \sqrt{\delta_{B}^{2}+\delta_{L}^{2}} \\
V P L=K_{V} \cdot \delta_{h}
\end{array}\right.
$$

b) a complete formula, which takes into account a correlation between mean errors of the designated ellipsoidal BLh aircraft coordinates [8]: 


$$
\left\{\begin{array}{c}
H P L=K_{H} \cdot \sqrt{\frac{\delta_{B}^{2}+\delta_{L}^{2}}{2}+\sqrt{\left(\frac{\delta_{L}^{2}-\delta_{B}^{2}}{2}\right)^{2}+\delta_{B L}^{2}}} \\
V P L=K_{V} \cdot \delta_{h}
\end{array}\right.
$$

where:

$K_{H}$ - coefficient of proportionality in the horizontal plane,

$K_{V}$ - coefficient of proportionality in the vertical plane,

$\left(\delta_{B}, \delta_{L}, \delta_{h}\right)$ - mean errors of the determined position using the SPP code method in the GLONASS satellite system,

$H P L$ - integrity of positioning in the horizontal plane,

$V P L$ - integrity of positioning in the vertical plane.

The HPL and VPL parameters are determined for stages of the aircraft flight. Therefore, the coefficient of proportionality $K_{H}$ and $K_{V}$ will express different values for air operations performed in the horizontal plane and the vertical plane. Within the procedure of non-precision approach NPA, the coefficient value $K_{H}$ is 6.18 [12]. On the other hand, in the framework of the SBAS APV approach procedure and the precision approach PA cat. I, parameter $K_{H}$ is 6.00 [10]. In case of the $V P L$ parameter, the value of this coefficient $K_{V}$ is 5.33 for the operations SBAS APV and PA cat. I [13].

\section{Research experiment}

The verification and checking the levels of integrity in an air operation were tested for an air experiment at the aerodrome in Chełm-Depułtycze Royal (ICAO aerodrome reference code: EPCD) in south-eastern Poland. The trajectory of the horizontal flight has been depicted in fig. 1. In the air experiment, the aircraft Cessna 172 was used. The flight began at 11:26:36 and ended at 12:09:24 in accordance with GPST. The position of the Cessna 172 was defined on the basis of observations and GLONASS navigation data registered by an onboard receiver Topcon HiperPro. On this basis it was possible to further examine the integrity of GLONASS positioning. In the calculations the authors adopted: the elevation angle of 5 degrees for GLONASS observations, the system of coordinates and their mean errors: ellipsoidal BLh, positioning method: SPP method, interval of computations: $1 \mathrm{~s}$, a priori error of GLONASS measurement observations: $1 \mathrm{~m}$, the values of coefficients: $K_{H}=6.18, K_{H}=6.00$ and $K_{V}=5.33$. The numerical calculations were conducted in the RTKLIB software, in the library RTKPOST [11]. 


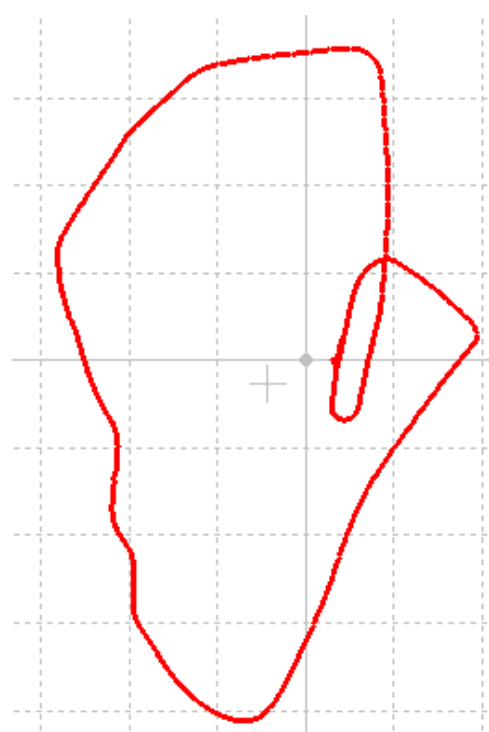

Fig. 1. The horizontal trajectory of the aircraft [source: based on RTKLIB software]

\section{Results}

The levels of integrity on the basis of the GLONASS solution in the SPP code method have been specified for individual air operations in air transport. In particular, the HPL and VPL parameters were designated for the NPA GLONASS approach, SBAS APV approach and precision approach PA cat. I. A visualization of the obtained results of HPL and VPL parameters was made in the Scilab v.6.0.0 programme [15]. In addition, Figures 2-4 illustrate the results obtained from the GPS solution for the same air experiment for control and check-up. In the GPS solution, the same boundary and initial conditions were adopted for parameters $\left(K_{H}, K_{V}\right)$, as in in the GLONASS solution.

Figure 2 shows the results of the HPL parameter in the GLONASS and GPS solution for the procedure of NPA GLONASS and NPA GPS. In the calculations of the parameter HPL, the authors used the coefficient value $K_{H}=6.18$. The HPL values in the GLONASS solution range from $51.2 \mathrm{~m}$ to $133.2 \mathrm{~m}$. Besides, the average value of the parameter HPL is equal to $56.3 \mathrm{~m}$. The HPL values in the GPS solution range from $19.1 \mathrm{~m}$ to $63.2 \mathrm{~m}$. Moreover, the average value of the parameter HPL is equal to $21.1 \mathrm{~m}$.

Figure 3 shows the results of the HPL parameter in the GLONASS and GPS solutions for the procedure of indirect approach SBAS APV and precision PA cat. I. In the calculations of the HPL parameter, the authors used the coefficient value $K_{H}=6.00$. The HPL values in the GLONASS solution range from $37.9 \mathrm{~m}$ to $119.4 \mathrm{~m}$. Besides, the average value of the HPL parameter is equal to $42.3 \mathrm{~m}$. The HPL values in the GPS solution range 
from $14.8 \mathrm{~m}$ to $56.0 \mathrm{~m}$. Moreover, the average value of the parameter HPL is equal to $16.6 \mathrm{~m}$.

Figure 4 shows the results of the VPL parameter in the GLONASS and GPS solutions for the procedure of indirect approach SBAS APV and precision PA cat. I. In the calculations of the parameter VPL, the authors used the coefficient value $K_{V}=5.33$. The VPL values in the GLONASS solution range from $48.4 \mathrm{~m}$ to $153.7 \mathrm{~m}$. Besides, the average value of the parameter VPL is equal to $56.0 \mathrm{~m}$. The VPL values in the GPS solution range from $20.0 \mathrm{~m}$ to $40.7 \mathrm{~m}$. Moreover, the average value of the parameter VPL is equal to $22.4 \mathrm{~m}$.



Fig. 2. The HPL values for GLONASS and GPS solution $(\mathrm{Kh}=6.18)$ [source: based on Scilab software] 


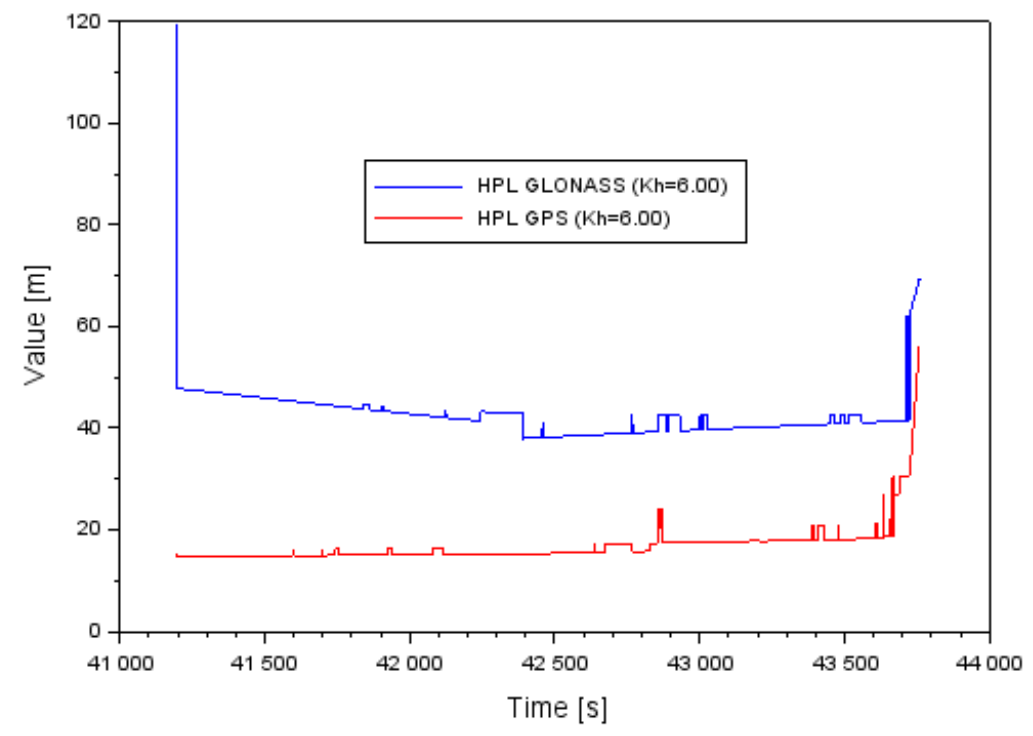

Fig. 3. The HPL values for GLONASS and GPS solution $(\mathrm{Kh}=6.00)$ [source: based on Scilab software]

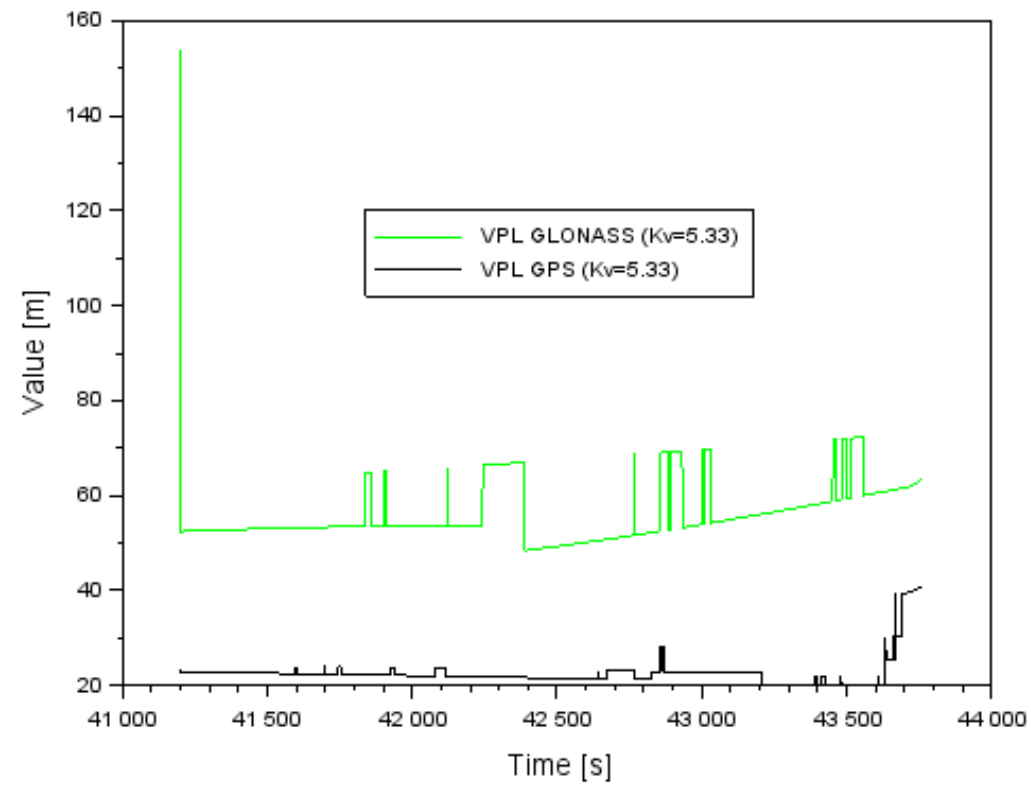

Fig. 4. The VPL values for GLONASS and GPS solution $(\mathrm{Kv}=5.33)$ [source: based on Scilab software] 


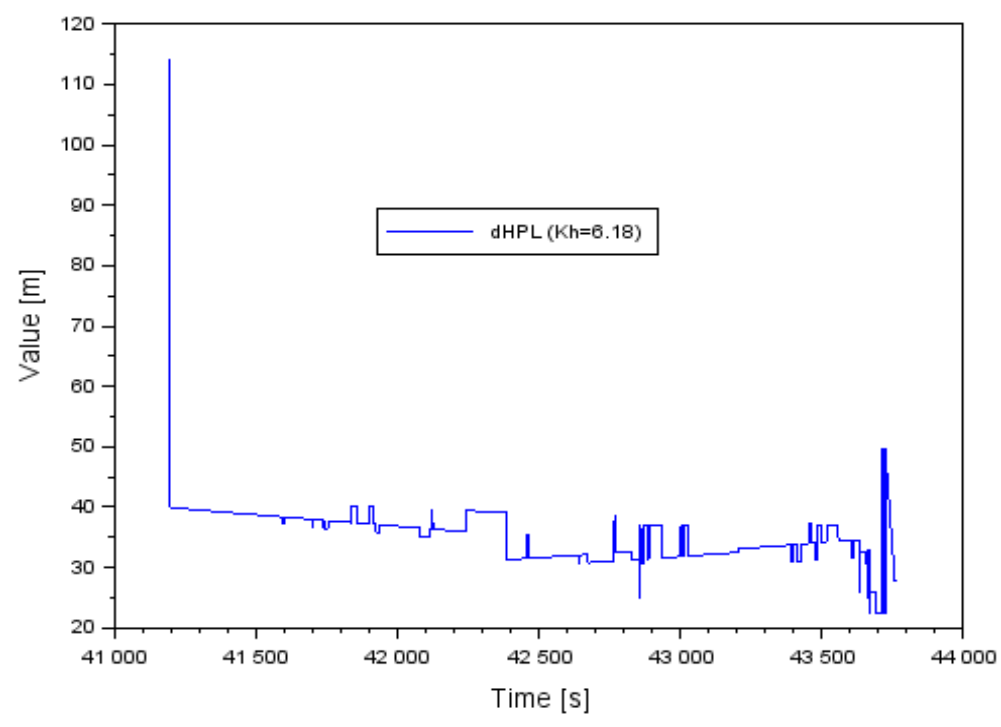

Fig. 5. Difference of HPL values between GLONASS and GPS solution (Kh=6.18) [source: based on Scilab software]

In the next stage of the research, the authors determined the difference in the obtained HPL and VPL values between the GLONASS and GPS solutions for a particular approach to landing procedure. For this reason parameters were determined as absolute values of the following mathematical formulas:

$$
\left\{\begin{array}{c}
d H P L=\left|H P L_{G L O}-H P L_{G P S}\right| \\
d V P L=\left|V P L_{G L O}-V P L_{G P S}\right|
\end{array},\right.
$$

where:

$d H P L$ - the difference between the levels of HPL integrity between GLONASS and GPS solutions in the horizontal plane,

$d V P L$ - the difference between the levels of VPL integrity between GLONASS and GPS solutions in the vertical plane.

Figure 5 shows the results of the dHPL parameter between solutions GLONASS and GPS for the NPA GNSS procedure. The dHPL values range from $22.5 \mathrm{~m}$ to $114.2 \mathrm{~m}$, respectively. Furthermore, the average value of the parameter dHPL equals $35.2 \mathrm{~m}$ and the error RMS is equal to $35.5 \mathrm{~m}$.

Figure 6 shows the results of the dHPL parameter between the GLONASS and GPS solutions for the procedure of an indirect approach SBAS APV and precision PA cat. I. The dHPL values are between $10.8 \mathrm{~m}$ and $104.5 \mathrm{~m}$, respectively. Furthermore, the average value of the parameter dHPL equals $25.7 \mathrm{~m}$, whereas of the RMS error it is equal to $26.1 \mathrm{~m}$. 
Figure 7 shows the results of the dVPL parameter between the GLONASS and GPS solutions for the SBAS APV procedure and precision PA cat. I. The dHPL values range from $22.0 \mathrm{~m}$ to $130.8 \mathrm{~m}$, respectively. Furthermore, the average value of the parameter dVPL equals $33.6 \mathrm{~m}$, while the error RMS is equal to $34.2 \mathrm{~m}$.

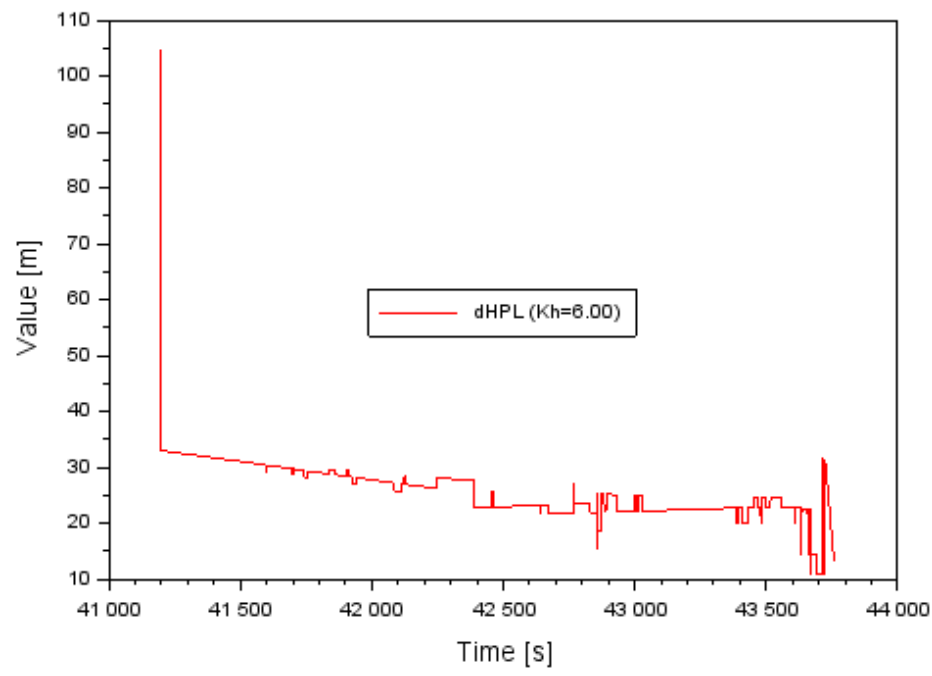

Fig. 6. Difference of HPL values between GLONASS and GPS solution (Kh=6.00) [source: based on Scilab software]

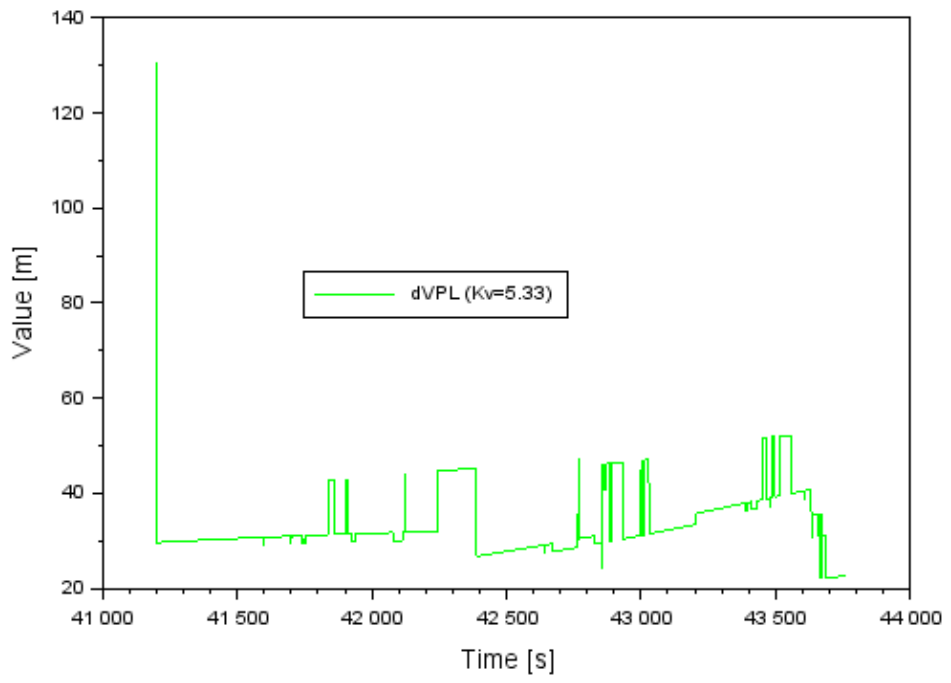

Fig. 7. Difference of VPL values between GLONASS and GPS solution $(\mathrm{Kv}=5.33)$ [source: based on Scilab software] 


\section{Discussion}

The problem of determining the HPL and VPL integrity levels in aviation has been raised in several research works. The paper [5] determines the levels of integrity of HPL and VPL for NPA GLONASS procedures in aviation. The results of HPL and VPL integrity were determined for the SPP code method and they do not exceed the value of $90 \mathrm{~m}$. Moreover, the work [6] demonstrates the values of the levels of integrity derived from the differential code DGLONASS solution. The obtained HPL and VPL results do not exceed the value of $17 \mathrm{~m}$. The work [9] shows designating VPL integrity levels by means of the GLONASS observations, within the GBAS augmentation system used in aviation. The obtained results of the VPL parameter do not exceed the values of 7-8 $\mathrm{m}$. The work [14] demonstrates HPL and VPL integrity levels, using the GPS/GLONASS observation within the RAIM module in the ABAS augmentation system used in aviation. The obtained HPL and VPL parameters do not exceed the value of $100 \mathrm{~m}$. The work [2] shows the levels of VPL integrity in the GPS/GLONASS, GPS/GLONASS/Galileo, GPS/Galileo/BeiDou and GPS/GLONASS/Galileo/Beidou solutions. The worst VPL results were obtained in the GPS/GLONASS solution, amounting to $40 \mathrm{~m}$, whereas the best ones in the GPS/ GLONASS/Galileo/Beidou solution, amounting up to 20-30 m. In addition, the work [10] designates the HPL and VPL parameters, using the GPS/GLONASS observations in an air test. The obtained integrity findings do not exceed the value of $30 \mathrm{~m}$.

By comparing the obtained HPL and VPL integrity levels with the works $[10,5,6,9$, $14,2]$, it can be observed that the values of the HPL and VPL levels in the GLONASS solution are on a similar level as in the works [5, 14] When a multi-system solutions are used (e.g. GPS/GLONASS) [2, 10] in aviation, the HPL and VPL values decrease, which authenticates the designated aircraft position. The best HPL and VPL results can be noticed for the GNSS positioning techniques used in the GBAS augmentation system $[6,9]$.

\section{Conclusion}

The article describes and presents the results of the determination of the HPL and VPL integrity for the GLONASS satellite system used in aviation. The paper determined the levels of HPL and VPL integrity for the selected approach to landing procedures. On the basis on the obtained results of the investigations, it was found that:

- HPL values for NPA GLONASS procedures are equal to $134 \mathrm{~m}$,

- HPL values for the indirect approach procedure SBAS APV and precision PA Cat. I are equal up to $120 \mathrm{~m}$ for the GLONASS solution,

- VPL values for indirect approach procedures SBAS APV and precision PA Cat. I are equal up to $154 \mathrm{~m}$ for the GLONASS solution,

- The HPL and VPL values in the GLONASS solution, on average, are overestimated with regard to the GPS solution, from $25 \mathrm{~m}$ to $35 \mathrm{~m}$.

Taking into account the requirements of the HPL and VPL integrity levels in aviation, it is possible to formulate a statement that GLONASS only satisfies the NPA GNSS procedures. 
What is more, GLONASS does not meet the integrity demands for indirect approach procedures SBAS APV and precision PA Cat. I [2]. Nevertheless, it is necessary to monitor the HPL and VPL integrity parameters in the GLONASS solution in aviation due to the fact that the GLONASS system possesses official certification in aviation.

\section{Acknowledgement}

The authors would like to express their gratitude for the available RTKLIB software package on the website: www.rtklib.com. This paper was supported by the Military University of Aviation for the year 2020.

\section{References}

1. Banaszek K., Malarski M.: Required navigation performance and risk of airport operations. Problemy eksploatacji, no 4, 2009 (in Polish).

2. El-Mowafy A.: Pilot evaluation of integrating GLONASS, Galileo and BeiDou with GPS in ARAIM. ARTIFICIAL SATELLITES, Vol. 51, No. 1, DOI 10.1515/arsa2016-0003, 2016.

3. Fellner A., Banaszek K., Trómiński P.: The Satellite Based Augmentation System EGNOS for Non-Precision Approach Global Navigation Satellite System. Transport Problems, Vol. 7, Iss. 1, 2012.

4. ICAO.: ICAO Standards and Recommended Practices (SARPS). Annex 10, Volume I (Radionavigation aids), 2006. Polish version. Available from: http://www.ulc.gov.pl/ pl/prawo/prawomi\%C4\%99dzynarodowe/206-konwencje,current on: 15.10.2018.

5. Krasuski K., Wierzbicki D.: Determination of reliability parameters of HPL and VPL technical safety in the procedure of a non-precision landing approach NPA GNSS with using GPS and GLONASS navigation systems in air transport. Scientific Journal of the Military University of Land Forces, Vol. 50, No. 2(188), 2018, DOI 10.5604 /01.3001.0012.2504.

6. Krasuski K., Ćwiklak J., Grzesik N.: Accuracy Assessment of Aircraft Positioning by Using the DGLONASS Method in the GBAS System. Journal of KONBiN, Vol. 45, Iss. 1, 2018, DOI 10.2478/jok-2018-0006.

7. Krasuski K.: Application the Single Difference Technique in Aircraft Positioning Using the GLONASS System in the Air Transport. Communications - Scientific Letters of the University of Zilina, 21(4), 2019.

8. Oliveira J., Tiberius C.: Quality Control in SBAS: Protection Levels and Reliability Levels. The Journal of Navigation, 62, 2009, DOI 10.1017/S0373463309005311.

9. Sayim I.: Performance Analysis of GBAS Vertical Protection Levels for Civil Aircraft Precision Approach and Landing using GPS and GLONASS. Afyon Kocatepe University Journal of Science and Engineering, 18, 2018, DOİ: 10.5578/fmbd.66811. 
10. Takács B., Siki Z., Markovits-Somogyi R.: Extension of RTKLIB for the calculation and validation of protection levels. Int. Arch. Photogramm. Remote Sens. Spatial Inf. Sci., XLII-4/W2, 2017, DOI 10.5194/isprs-archives-XLII-4-W2-161-2017.

11. Takasu T.: RTKLIB ver. 2.4.2 Manual, RTKLIB: An Open Source Program Package for GNSS Positioning, 2013, Paper available at website: http://www.rtklib.com/ prog/manual_2.4.2.pdf, current on 2019.

12. Tiberius C., Odijk D.: Does the HPL bound the HPE? NAVITEC 2008 4th ESA workshop on satellite navigation user equipment technologies, Noordwijk, 2008.

13. Walter T., Blanch J., Enge P.: Vertical Protection Level Equations for Dual Frequency SBAS. Proceedings of the 23rd International Technical Meeting of the Satellite Division of The Institute of Navigation (ION GNSS 2010), Portland, OR, September 2010.

14. Walter T., Blanch J., Choi M. J., Reid T., Enge P.: Incorporating GLONASS into Aviation RAIM Receivers. Proceedings of the 2013 International Technical Meeting of The Institute of Navigation, San Diego, California, January 2013.

15. URL1.: https://www.scilab.org, current on 2020. 